\title{
Further Validation of the Systematic Screening for Behavior Disorders in Middle and Junior High School
}

\author{
Paul Caldarella \\ Paul_Caldarella@byu.edu \\ Michael Richardson \\ michael_richardson@byu.edu \\ Ben Young
}

Follow this and additional works at: https://scholarsarchive.byu.edu/facpub

Part of the Teacher Education and Professional Development Commons

Original Publication Citation

OSEP Conference, Washington D.C. (July 28)

\section{BYU ScholarsArchive Citation}

Caldarella, Paul; Richardson, Michael; and Young, Ben, "Further Validation of the Systematic Screening for Behavior Disorders in Middle and Junior High School" (2008). Faculty Publications. 22.

https://scholarsarchive.byu.edu/facpub/22

This Poster is brought to you for free and open access by BYU ScholarsArchive. It has been accepted for inclusion in Faculty Publications by an authorized administrator of BYU ScholarsArchive. For more information, please contact ellen_amatangelo@byu.edu. 


\section{Further Validation of the Systematic Screening for Behavior} Disorders in Middle and Junior High School

Paul Caldarella, Ph.D., Michael J. Richardson, M.S., \& Benjamin J. Young, B.S. Brigham Young University

Positive Behavior Support Initiative

Screening for Students At-Risk for EBD

Screening for EBD allows for prevention and early intervention,
which can reduce the need for more intensive services. Althoug here has been an emphass on screening in elementary schook,

$>$ The Systematic Screening for Behavior Disorders (SSBD) is multi-gated screening system for use in elementary schools. Advantages include relative ease of administration and potential
to consider all students in a school before using more intrusive, time consuming measures.

$>$ Recent research (Caldarella, et al. 2008) evaluated the SSBD for use in secondary schools and revealed statistically significant dififerences between students identilied hrough $\mathrm{SSBD}$ screen and non-dientified students on office disciplinary referrals
(ODR) and cumulative grade point averages (GPA). Sign ffiction correlations between scores on the SSBD and on other well established teacher rating scales were also found.

- The current study extends these findings by examining ratings, and student self-ratings of belpvior.

\section{Sample \& Setting}

$>$ Participants were from two suburban secondary schools in
Utah; a middle (grades 6-7) and junior high (grades 7-9) schoo

Total Students $\quad 2173$

Male/Female $\quad 1087 / 108$

Free, Reduced L

African-Am
Asian

Asian

Hispanic

Native American

$30 \%$
$.5 \%$

$1 \%$

$89 \%$
$8 \%$

Pacific slander

$1 \%$
$.5 \%$

> Students nominated for participation via the SSBD:

Nominated Students

Intermalizing

$\begin{array}{ll}\text { Students Invited to Participate } & 123 \\ \text { Students receiving follow-up measures } & 66\end{array}$

226
109
117
123
66

> Seventy-three percent of nominated students were male, $84 \%$ (African American, Native American, Asian, and Pacific Islander) comprised roughly three percent of the nominated students.

\section{Research Aim:}

Examined evidence for the validity of using the SSBD in secondary school settings.

Results \& Discussion

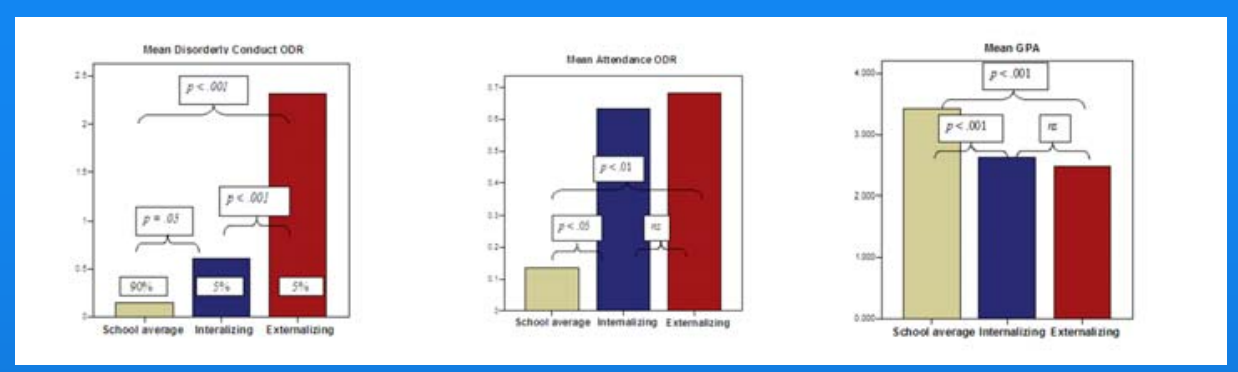

Statistically significant differences were found between students nominated at Stage One (for exhibiting internalizing and externalizing behaviors) on externalizing behaviors on attendance ODR or GPA, though they did differ significantly from each other on disorderly conduct ODR.

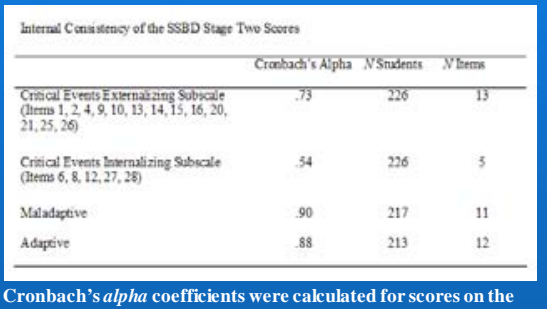

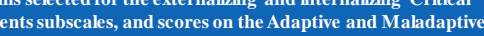

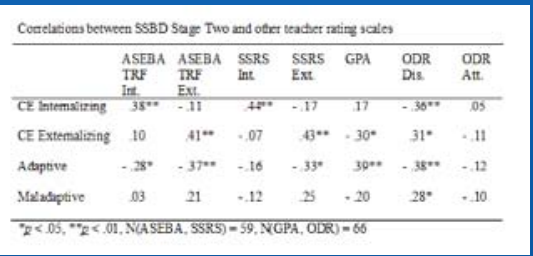

Pearson's $r$ calculations for scores on the SSBD Stage Two measures and on scores obtained from other teacher rating
measures also yielded several significant correlations.

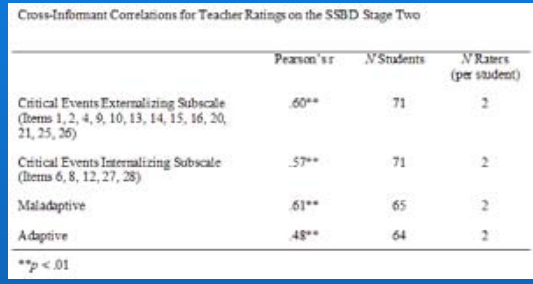

son's $r$ calculations yielded statistically significant $(p<.01)$ "cross-informant" correlations for scores on the
SSBD Stage Two scales when more than one teacher SSBD Stage Two scales wh

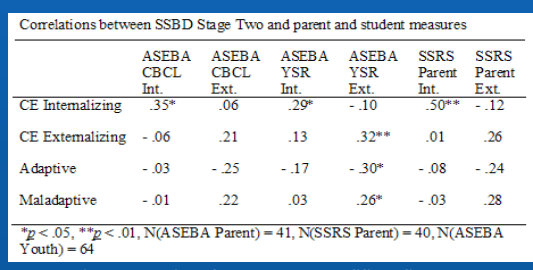

Pearson's r calculations for scores on the SSBD Stage Two measures and on scores obtained from parent rating and student self-rating measures also yielded several statistically
Procedures \& Measures

$>$ Three behavior rating scales were used in this study: the SSBD 2001), and the SSRS (Gresham \& Elliot, 1990). Stage One nvolves nomination of students who exhibit internalizing or externalizing behavior, and ranking them according to severit. Stage Two includes a behavior checklist and two rating scales: contain internalizing and externalizing subscales.

> Classroom teachers completed the SSBD (Stages One and Two) TRF) and SSRS during a staff meeting at the school. Parent participants completed the parent forms of the ASEBA
(the Child Behavior Checklist-CBCL) and the SSRS. Forms were sent home with students, mailed to parents, or delivered by researchers.

> Student participants completed the ASEBA (the Youth Self Report-YSR) during an invited lanch. Instructions were read aloud and questions were clarified as requested by students. $>$ Two additional measures were obtained from existing school data
sources (a district database): office disciplinary referrals (ODR)

Limitations \& Conclusions $>$ The sample of students was relatively small. The population from which these students were drawn also lacked geographic
and ethnic diversity, and did not include high school students. In addition, no formal item analysis was conducted.

> Findings indicate that parent and self-ratings, as well as SOmparison teacher ratings, support the validity of using the between ratings on the SSBD and student and parent ratings on other behavioral measures are of particular interest for this study, and support prior research on the use of the SSBD in

Contact Information \& References

Briahom Voung University Positive Behavior Support Initiative

http://education.byu.edu/pbsi/index.html

byu.pbsi@gmail.con
(801) 377-0560

Achenbach, T. M, \& Rescorla, L. A. (2001). Manual for the ASEBA school-age
forms \& profiles. Burlingion, VI. Univessity of Vermont, Research Center for
Children, Youth, \& Fanilies.

Caldarella, P., Young, E. L., Richardson, M. J., Young, B. J., \& Young, K. R.
(2008), Validation of the Systematic Screening for Behavioral Disorders in

(2008). Validation of the Systematic Screening for Behavioral Disoridet
middle and junior high school. Journal of Emotional and Behavioral
Disorders $16,105-117$.

Gresham, F. M, \& Elliot, S. N. (1990), Social Skills Rating System manual. Circl
Pines, MN: American Guidance Sevice.

Walker, H. M., \& Severson, H. H. (1992). Systematic St
Disorders (2nd ed.). Longmont, CO: Sopris West. 